DOI: 10.2478/linpo-2014-0002

\title{
Discourse about the end of the world
}

\section{Dorota Brzozowska}

Institute of Polish and Cultural Studies, Opole University, dbrzozowska@uni.opole.pl

\begin{abstract}
Dorota Brzozowska. Discourse about the end of the world. The Poznan Society for the Advancement of the Arts and Sciences. PL ISSN 0079-4740, ISBN 978-83-7654-384-0, pp. 29-40

The increased prevalence of discourse concerning the expected end of the world was observed in various countries and manifested in various genres especially in the years 2000 and 2012. Some of the discourse was conducted in a serious manner, whereas other instances included humorous motifs and were used for commercial purposes.

The aim of this paper is to take a closer look at the typical motifs prevailing in the discourse concerning the end of the world, with special emphasis on the humorous aspect - both universal and culturespecific. Texts found on Polish, German, English and Russian websites were analyzed.

In the studied material, the end of the world was understood literally and broadly - in terms of extermination of the human race, eschatology - or narrowly, in terms of statistical data concerning the death of a given number of people, or even individually, referring to the imminent ending of each person's particular world. The metaphorical meaning of the end of the world was also used in the sense of "a commotion", "the pressure of business", "a mess, confusion", and "accumulation of problems", referring mostly to the functioning of particular institutions or lack of access to the Internet, or reviving common stereotypes.
\end{abstract}

Keywords: the end of the world, discourse, humor, stereotypes, websites

\section{Introduction}

Recent years, and in particular the years 2000 and 2012, have abounded in discourse concerning the expected end of the world. This could be observed in various countries, and was manifested in various genres. All kinds of publications were reissued - from ancient to the most recent - concerning prophecies claiming that by the end of the century or precisely in 2012 the world would be destroyed; new books analyzing the old forecasts were published; disaster films such as 2012 and Melancholia enjoyed enormous popularity; and websites dedicated exclusively to Armageddon were created. People were reminded of the dates of the previous expected ends of the world, many of which could be found in history, and which for many people did indeed end tragically, for instance in the case of group suicides committed by various sect members. In different parts of the world people were either 
preparing for the end, or making fun of those who believed in the prophecies. Some parts of the discourse were conducted in a serious manner, whereas others included humorous motifs and were used for commercial purposes.

The objective of this paper is to take a closer look at the typical motifs prevailing in the discourse concerning the end of the world, with special emphasis on the humorous aspect - both universal and culture-specific. To present some of its manifestations, I will use texts found on Polish, German, English and Russian websites. This material is quite useful as it is possible to indicate the precise date of its publication on the Internet, and in order to make it comparable, I will use as illustrations selected examples representing a relatively new genre of humorous texts: demotivational posters, also called demotivators. ${ }^{1}$

\section{Books about the end of the world}

An analysis of the titles of recently published books (100 titles of Polish and translated books available in domestic Internet bookstores were considered; the Bibliography lists some of them) reveals the key words in the discourse concerning several semantic areas, sometimes overlapping:

The time scope: time, times, year, millennium, dates: 2000, 2012, 21.12.2012, end, history, stories.

Prophecies concerning the future: prophecy (coming true, not coming true), prophets, (biblical) prophecies.

Religion: Christ - the second coming, Anti-Christ, biblical (prophecies).

The final events: disaster, catastrophe, extermination, threat, Armageddon, Apocalypse, the end of the world, the end of time, the last days, eschatology.

Feelings and states: fear, shadow (of the millennium, of extermination), faith, hope (of survival), uncertainty - emphasized by the occurrence of questions or question marks.

Expressions referring to authors of prophecies: Nostradamus, Hildegard of Bingen, the Maya peoples (the Maya calendar).

As this superficial overview of selected titles ${ }^{2}$ indicates, discourse concerning the end of the world is filled with a strongly negative charge, even though in the majority of the presented works their rationality as well as the legitimacy of belief in the cataclysm are denied.

One of the mechanisms for criticizing, exposing and overcoming the fear of and belief in a cataclysm was to make fun of it and of those who proclaimed or merely believed in it.

${ }^{1}$ A demotivator is a combination of a suggestive drawing or a photo with a commenting caption. Demotivational posters are mostly cynical or ironic. They started out as a parody of the motivational posters present in many (usually American) offices, which were supposed to motivate employees to work harder and achieve their targets. They spread very quickly as commentaries and responses to topical media subjects (Piekot 2012; Baran 2012).

2 Such discourse was so popular that it became known as the "2012 phenomenon", “Феномен 2012 года". http://en.wikipedia.org/wiki/2012_phenomenon. (Accessed 2013-05-02.) 


\section{Cultural dimensions}

In order to properly interpret the texts originating in a particular culture, we should take into consideration not only the context of their occurrence, but also the characteristics of the culture itself, e.g. the cultural dimensions that can be discerned in it. Cultural dimensions are "orientations covering the ways in which human beings deal with each other, a different way in which societies look at time and the attitude of the culture to the environment" (Trompenaars \& Hampden-Turner 2002: 21). ${ }^{3}$ If we treat these as a starting point for the interpretation of discourse concerning the end of the world by particular recipients, we can notice that the most significant dimension here will be Uncertainty Tolerance versus Uncertainty Avoidance. All those for whom the unknown is perceived as dangerous will at all costs attempt to guess and foresee what awaits them, so that they can get ready for all eventualities. Such people will be more inclined to make projections about the future, but they will also be more afraid of the future than those who await changes as something interesting. Another dimension - Neutrality versus Emotionality - is also of importance here. More emotional people will more easily succumb to panic, or at least demonstrate it more frequently.

Control of Nature versus Harmony with Nature is a dimension best visible in discourse concerning the causes and consequences of cataclysms related in particular to the elements which are beyond human control. People assuming that man should submit to nature will more easily accept the fact of the world's end as a natural course of events. Those who want to be rulers of the world realize that they do not have influence over everything - for example, they cannot prevent meteorites from falling - and this makes them more frustrated, but they will also try to protect themselves from extermination to the last moment, for example by making reserves of food, or building and furnishing shelters.

Another dimension present in the analyzed discourse is Universalism versus Particularism. Some of those commenting on information concerning the end of the world state that it is not important when the world will end for everybody, it is important when it will end "for me" - and this may happen at any time and it does not necessarily have to be spectacular.

Time perception and Monochronic versus Polychronic approaches are also of fundamental significance with regard to a prophecy, since it is embedded in time - it is an attempt to grasp the future by drawing conclusions from the present. Hence we see all kinds of interpretation of signs, observing and attributing them to some previously heralded facts; this category includes, for instance, the fears based on Nostradamus's prophecies that a black Pope will be the last one and then the world will end, and the interpretation of the unexpected abdication of Benedict XVI accompanied by a series of lightning strikes on the Vatican as a harbinger of the election of the last pope. Mockery of the prophecy of the end of the world also referred to the time dimension, where people asked at what time or according to which time zone it would take place.

${ }^{3}$ Researchers propose several oppositions of cultural dimensions, e.g. Low versus High Context; Femininity versus Masculinity; Low versus High Power Distance; Uncertainty Tolerance versus Uncertainty Avoidance (proposed by Hofstede 2000); Neutrality versus Emotionality; Achievement versus Ascription orientation; Universalism versus Particularism (Trompenaars \& Hampden 2002); Control of Nature versus Harmony with Nature; Monochronic versus Polychronic approach (Hall 1978, 1999). 
In publications, polemics were also engaged in by representatives of two interpretative options: Low versus High Context. The former claim that all prophecies should be understood literally, the latter that they simply lead us to a more oblique reality. Thus, from the moment the prophecies referring to the Mayan calendar appeared, experts in the Mayan culture attempted to convince us that what was meant was only a symbol of the end of a particular epoch, and not necessarily a total extermination. Those who understand the world in a low context manner were obviously not convinced by such explanations. The religious attitude of those taking part in the discussion was of some importance too, as some felt closer to secular prophecies, and others to religious ones. The Christian belief based on St. Matthew's Gospel: "Watch therefore, for ye know neither the day nor the hour wherein the Son of man cometh" (Mt 25:13) prevented some people from trusting any specific dates of the end of the world. Depending on particular religions, this vision was either pessimistic or optimistic - awaiting the parousia as the second coming of Christ may be understood as awaiting the victory of good and the final defeat of evil in the world.

Depending on the ideas professed, there are various causes of the end of the world man himself, or external forces, such as nature or God. All of these attitudes and dimensions can be found in the analyzed material which will be described in this paper.

\section{Internet material}

The scale and scope of the issues discussed were considerable. This can be proved by the wealth of theories concerning the end of the world. A very well prepared and systematic list of these theories can be found on the websites created especially for this subject matter. One of the sites, in German, is entirely dedicated to these issues and comprises a detailed analysis of 26 theories:

Die Theorien zu 2012: Der Mayakalender, Die Prophezeiungen des Nostradamus, Das Sonnensystem 2012, Nibiru / Planet X, Polsprung und Sonnenstürme, Viren und Bakterien, Der Bibel Code, Die Hopi Indianer, Prophezeiung der Zulu, Prophezeiung des Malachias, Vorhersage der Ägypter, Gamma-Blitze, Johannes von Jerusalem, Der Asteroid Toutatis, Finanzkrise 2012, Kali-Yuga, Palmblattprophezeiungen, Maori Prophezeiung, 2012 und Ausserirdische, Neue Eiszeit 2012, 3. Weltkrieg, Aufstand der Maschinen, Bundeslade und 2012, Komet Elenin, Geoengineering, Alois Irlmaier. ${ }^{4}$

'The theories concerning 2012: the Maya Calendar, the Prophecies of Nostradamus, the Sun System 2012, Nibiru / Planet X, the Pole Shift and Sunstorms, Viruses and Bacteria, the Bible Code, the Hopi Indians, Zulu Prophecy, St Malachy's Prophecy, the Egyptians' Predictions, Gamma-ray bursts, Johannes of Jerusalem, the Toutatis Asteroid, Financial Crisis 2012, Kali-Yuga, the Palm Leaves Prophecy, the Maori Prophecies, 2012 and the Extraterrestrials, New Ice

4 http://www.21dezember2012.org. (Accessed 2013-04-02.) A similar number of theories can also be found on English websites, e.g. http://endoftheworld2012.net/ (Accessed 2013-04-02.) 
Age 2012, World War III, the Rise of the Machines, Ark of the Covenant and 2012, the Elenin comet, Geoengineering, Alois Irlmaier'.

Apart from scientific analyses, on the German websites one can also find such jokes as the following:

"Weltuntergangsprophezeiung"

Der Klassenlehrer schildert den Schülern den Weltuntergang am 21. Dezember 2012: „Der Sturm wird die Dächer wegfegen, Flüsse werden ueber die Ufer treten und Donner und Blitz werden ueber die Welt hereinbrechen! " Fragt eines der Kinder: ,, Werden wir bei dem Sauwetter Unterricht haben müssen “?"

"Doomsday Prophecy"

The class teacher describes to the school children the Doomsday on 21 December 2012:

"The Storm will sweep away roofs, rivers will flood and thunders and lightning will befall to the world!"

One of the children asks: "Will we need to have lessons at such awful weather?"

On various websites, including Polish ones, comments reminding people of the previous prophecies which did not come true were typical:

"The end of the world on 21 December? We have already survived several Armageddons."

On 21 December the world will end-many people believe it and scientists'denials are of no use at all. It is neither the first nor the last date of the prophesized end of the Earth, though.

The article describes five previous dates of supposed ends of the world (e.g. 31 December 999 - when New Year's Eve parties started; 1 January 2000 - connected with the fear of the so-called Millennium Bug), and seven dates in the future (e.g. 2060 - calculated by Isaac Newton based on his interpretation of the Bible, or a time in 10 sexdecillion years when according to astronomers' predictions, the heat death of the Universe may take place). ${ }^{6}$

The prophecies were taken seriously much earlier in fear of potential suicides:

"An Apocalypse in 2012? A suicide wave? An alarm in France”

The French sect-combating office warned against a flood of new sects and a suicide wave which might occur in relation to the prophecies. The report recalled the fact that in the past decades there were several group suicides connected with the "apocalyptic".

${ }^{5} \mathrm{http}: / /$ www.gute-witze.at/witz/lustige-witzige-nachrichten/weltuntergang-witze. (Accessed 2013-04-02.)

${ }^{6} \mathrm{http}: / /$ www.tvn24.pl/ciekawostki-michalki,5/koniec-swiata-21-grudnia-juz-kilka-armagedonowprzezylismy,294485.html. (Accessed 2012-12-20.)

$7 \mathrm{http}: / /$ www.tvn24.pl/wiadomosci-ze-swiata,2/apokalipsa-w-2012-roku-fala-samobojstw-alarm-wefrancji,175197.html. (Accessed 2011-06-19.) 
Discourse concerning the end of the world brought about actual preventive or preparatory activities. These are reflected in titles presenting information concerning various places, usually little picturesque villages located at the foot of a mountain or hill, in which one can safely wait out the end of the world:

A new place for the end of the world. Indicated by a Yogi. ${ }^{8}$

A quiet Turkish village besieged for "the end of the world"

The local authorities' and population's reactions varied from joy resulting from the expected influx of tourists and related profits to actions aiming at discouraging any potential visitors. Restaurant and pub owners in various parts of the world encouraged people to make reservations for a table in order to have an apocalyptic meal or drink.

The following headlines show that there were also some preparatory actions of a different nature:

The Russians are buying out Byelorussian tinned meat for "the end of the world"10

33 schools in the USA have been closed. One of the reasons is "the end of the world"'11

Various stations conducted surveys in which they asked questions such as:

What would you do if the world were to end tomorrow? Write to us about it! ${ }^{12}$

Internet users' reactions varied from serious to ridiculing:

The end of the world will take place when the final episode of "The Bold and the Beautiful" is screened. Until then we may sleep peacefully. Regards, Adam ${ }^{13}$

What time is the END OF THE WORLD to take place, so that I do not miss it?? Good golly, hehehe ${ }^{14}$

Advice given in articles of the type: "12 things to do before the end of the world" was in a similar mood:

"Hunt" for an attractive person with whom you would not be able to live your entire life and marry him/her for just a bit longer than a week. ${ }^{15}$

${ }^{8}$ http://www.tvn24.pl/wiadomosci-ze-swiata,2/nowe-miejsce-na-koniec-swiata-wskazal-jogin,294022. html. (Accessed 2012-12-11.)

${ }^{9}$ http://www.tvn24.pl/wiadomosci-ze-swiata/senna-turecka-wioska-oblezona-na-koniec-swiata,293913. html. (Accessed 2012-12-11.)

${ }^{10} \mathrm{http}: / /$ www.tvn24.p1/wiadomosci-ze-swiata,2/rosjanie-wykupuja-bialoruskie-konserwy-na-koniecswiata,294047.html. (Accessed 2012-12-12.)

${ }^{11} \mathrm{http}: / /$ www.tvn24.pl/wiadomosci-ze-swiata,2/33-szkoly-w-usa-zamkniete-wsrod-powodow-koniecswiata,295764.html. (Accessed 2012-12-18.)

${ }^{12} \mathrm{http}: / / w w w . r m f 24 . p 1 / n e w s-c o-b y s-z r o b i l-g d y b y-s w i a t-j u t r o-m i a l-s i e-s k o n c z y c-n a p i s z-d o-, n I d$, 764544\#postAddForm. (Accessed 2012-12-20.)

${ }^{13} \mathrm{http}: / /$ www.rmf24.pl/news-co-bys-zrobil-gdyby-swiat-jutro-mial-sie-skonczyc-napisz-do-,nId, 764544\#postAddForm. (Accessed 2012-12-20.)

${ }^{14} \mathrm{http}: / /$ www.rmf24.pl/news-co-bys-zrobil-gdyby-swiat-jutro-mial-sie-skonczyc-napisz-do-,nId, 764544\#postAddForm. (Accessed 2012-12-20.)

${ }^{15} \mathrm{http}: / / w w w . t v n 24 . p 1 /$ wiadomosci-ze-swiata,2/12-rzeczy-do-zrobienia-przed-koncem-swiata,294114.html. 
Various companies tried to profit from the prophecies concerning the end of the world, using the motif in advertisements for their products both before and after 21 December 2012. In Poland, the most famous advertisement was presented by Toyota in its humorous campaign promoting sales of its 2012 car models, originally with the slogan:

"There will be no end of the world", which was later changed to: "There was no end of the world, so buy a car for a long time". ${ }^{16}$

Journalists also reported on the numerous ridiculing texts on the Internet:

The Internet makes fun of the "Apocalypse". You cannot prevent something? Ridicule it! That is the point of view of the Internet users who make fun of the end of the world expected to take place today. Memes relating to this occasion are most popular on the Net. ${ }^{17}$

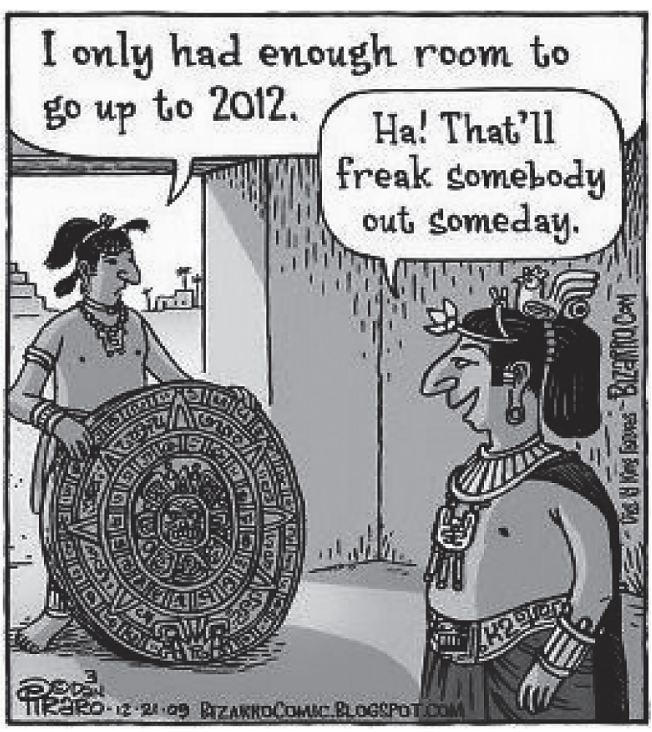

http://pinterest.com/pin/ 09.2012. (Accessed 2012-12-22.)

16 "Końca świata nie będzie", "Nie było końca świata, kup samochód na lata”, http://zapiskibrandmanagera.bloog.pl/id,332797546,title,Koniec-swiata-w-reklamie-czyli-dlaczego-Majowie-jednak-sie-rozmyslili,index. html?ticaid=6108fb. (Accessed 2012-12-28.)

${ }^{17}$ http://www.tvn24.pl/ciekawostki-michalki,5/internet-drwi-z-apokalipsy,295870.html. (Accessed 2012-12-21.) 
Also in this category are demotivational posters making an ongoing commentary on all events related to the theories about the end of the world. Before 21 December 2012 the following comments could be found:

(13)

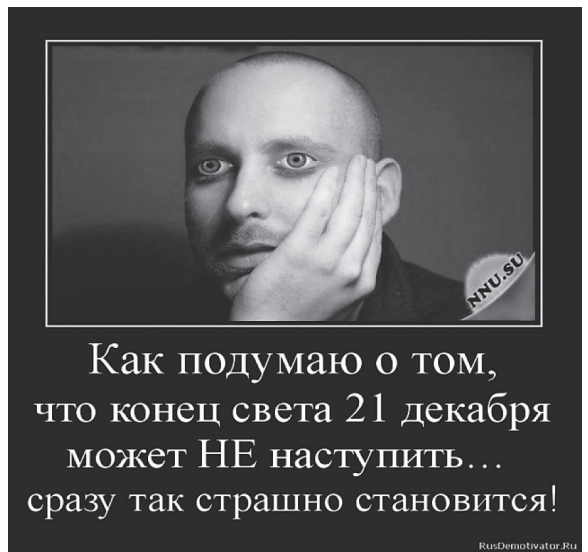

'As I think that the end of the world may not happen on the 21 st of December I get scarred immediately!'

http://rusdemotivator.ru. (Accessed 2012-10-30.)
(14)

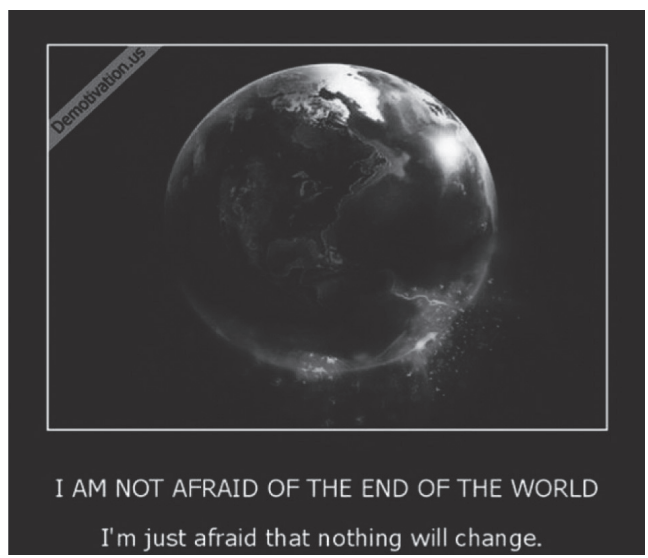

http://izifunny.com/demotivators/page/30/(Accessed 2012-12-21.)

On the day of the expected end of the world many new demotivators appeared on the site. Some of them made use of universal motifs such as cats, or images of the globe - a very popular picture related to cataclysm in various cultures.

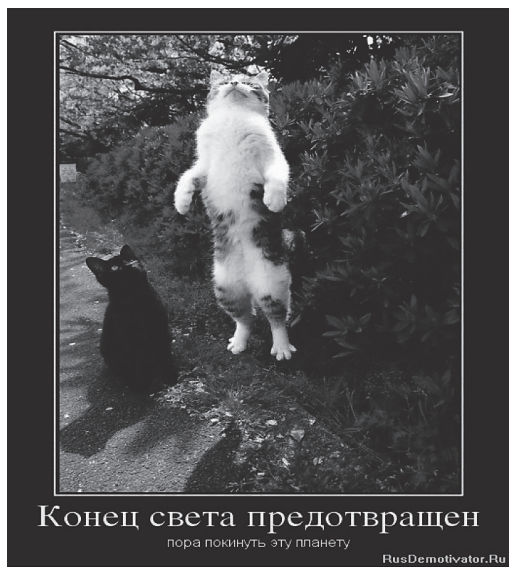

'The end of the world is coming. We need to leave this planet'. http://rusdemotivator.ru/surovyj-chelyabinsk (Accessed 2012-12-22)
(16)

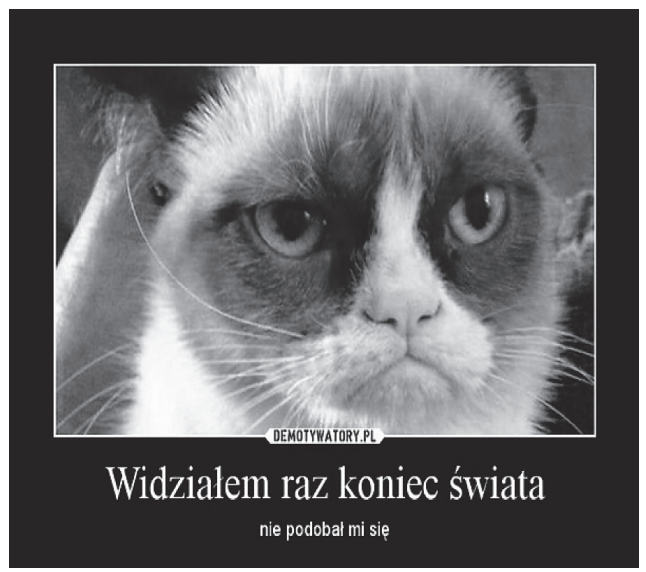

'I could see the end of the world once. I didn't like it'. http://izifunny.com/demotivators/page/30/(Accessed 2012-12-21.) 
On the days following the critical date, demotivational posters still referred to the end of the world:

(17)

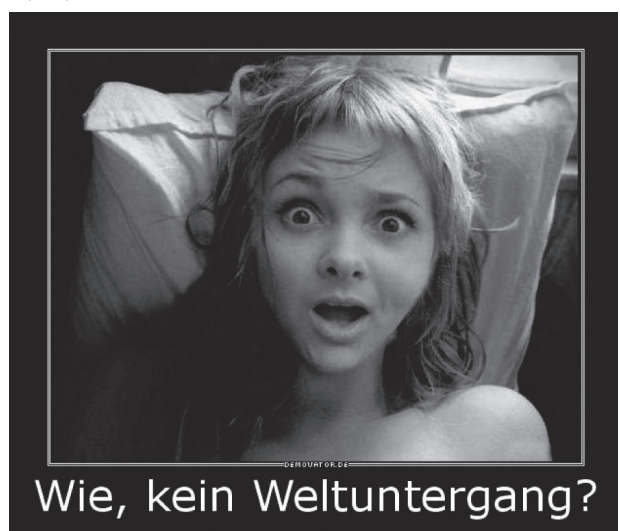

'What? No end of the world?'

http://demovator.de/wie-kein-weltuntergang-m6q4z. (Accessed 2012-12-22.)

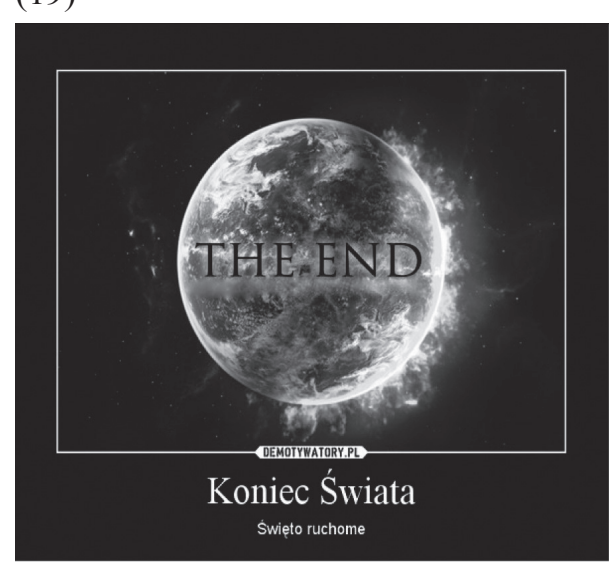

'The end of the world

Moving festival'

http://demotywatory.pl. (Accessed 2012-12.23.)

\section{(19)}

(18)

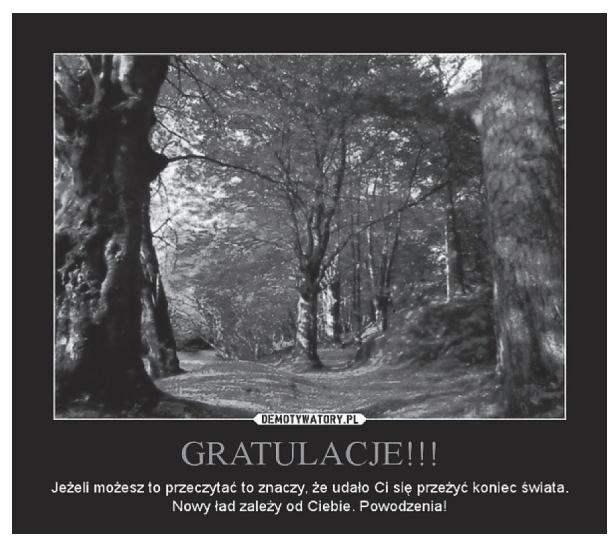

'CONGRATULATIONS!!!

If you can read it, it means that you have managed to survive the end of the world.

The new order depends on you. Good luck!'

http://demotywatory.pl. (Accessed 2012-12-22.) 
Internet users made similar comments in their blogs, as if expressing their dissatisfaction that nothing had changed:

$$
\begin{aligned}
& \text { And what? Sham! We have been deceived! By whom? The Maya this time! }{ }^{18} \\
& \text { And I still have to pay back my loan... For how long!? }{ }^{19}
\end{aligned}
$$

\section{Conclusions}

Summing up the linguistic and cultural images emerging from the discourse about the end of the world, we should underline its multidimensionality, connected with the wealth of genres in which it was presented, both in a bona fide manner (e.g. press commentaries, radio programs, scientific papers in astronomy, history, meteorology and psychology concerning such phenomena as planetary movement, global warming, group suicides, etc.) and in a non bona fide manner (e.g. funny advertisements, funny drawings, linguistic jokes, amusing comments and demotivators). The expected end of the world was commented on long before the critical date, and when nothing happened, the reasons why were analyzed, and almost immediately considerations were made concerning the next end of the world.

Four keynotes can be distinguished among the humorous themes. One of them is the political theme, set in the reality of each country, and usually of local scope. The three remaining keynotes are related to events publicized simultaneously in many countries. The end of the Mayan calendar, fear of a celestial object hitting the Earth confirmed by a meteorite rain in Russia, and a strong religious motif are all of this type. The religious motif referred to the Bible, and in particular to the Apocalypse, as described in the New Testament. It intensified, particularly in Catholic countries, after the events initiated by the unexpected abdication of the Pope. The aspects most intensely commented upon were the lightning strikes of the Vatican, as well as hope for the prophecy concerning the election of a black pope coming true.

The end of the world was understood literally and broadly - in terms of extermination of the human race, eschatology - or narrowly, in terms of statistical data concerning the death of a given number of people, or even individually, reminding people that everyone will die one day and one's individual world will end then. The metaphorical meaning of the end of the world was also used in the sense of "a commotion", "the pressure of business", "a mess, confusion", "accumulation of problems", referring mostly to the functioning of particular institutions, or the absence of access to the Internet, or sporadically reviving common stereotypes concerning women, through joking that the tragedies affecting them is expressed by the statement: "I have nothing to wear."

After the critical date, when no terminal events took place, the discourse concerning the end of the world gradually started to become blurred with other issues. For some time two types of comments continued to appear: optimistic ones - since we have survived, it will only get better now and nothing is frightening anymore -, and pessimistic ones - "this world is so hopeless that it is not even capable of coming to an end." Simultaneously, however, new futuristic discourse concerning the end germinated, and people started searching for new dates, along with deliberations concerning when and if the end will actually take place.

\footnotetext{
${ }^{18} \mathrm{http}: / /$ zzyycciiee.bloog.pl/id,332745972,title,no-i-po-koncu-swiata. (Accessed 2012-12-21.)

${ }^{19} \mathrm{http} / / /$ zzyycciiee.bloog.pl/id,332745972,title,no-i-po-koncu-swiata. (Accessed 2012-12-27.)
} 
Thus in the eschatological discourse itself, the assumption that the end is perceived as the beginning of something new, as a new birth, becomes clearly visible. By nature, scientists have a low level of fear of the unknown - this motivates them and enhances their willingness to learn more. In the scientific world, the continuity of thought and the ability to sow the seeds of curiosity - transmitting knowledge and analytical competencies, the ability to stimulate intellectually and to leave a trace in other people's minds - are of importance as well. Let me express my gratitude to the esteemed Professor celebrating her anniversary by assuring her of my fond memories of her. Let the statement that the end is the beginning, that new things are interesting, that everything changes, but nothing really ends, provide the form of my wishes: Many more years of creative work and Happy Birthday, dear Professor!

\section{References}

Baran, Anneli. 2012. Visual humour on the Internet. In Laineste, Liisi \& Brzozowska, Dorota \& Chłopicki, Władysław (eds), Estonia and Poland. Creativity and tradition in cultural communication. Tartu: ELM Scholarly Press.

Brzozowska, Dorota. 2008. Polski dowcip etniczny. Stereotyp a tożsamość. Opole: Wydawnictwo Uniwersytetu Opolskiego.

Brzozowska, Dorota. 2009. Kulturowe uwarunkowania tekstów humorystycznych na przykładzie tekstu „Chińska zupka" kabaretu Ani Mru Mru. Stylistyka 18. 337-349.

Brzozowska, Dorota \& Chłopicki, Władysław (eds.). 2012. Polish Humour (Humour and Culture 2). Kraków: Tertium.

Brzozowska, Dorota \& Laineste, Liisi. 2014. Humorous discourses about the end of the world in Poland and Estonia. In Baran, Anneli \& Laineste, Liisi \& Voolaid, Piret (eds.), Scala Naturae. Festschrift in Honour of Arvo Krikmann, 357-388.Tartu: ELM Scholarly Press.

Davies, Christie. 1990. Ethnic Humor Around the World. A Comparative Analysis. Indiana: Indiana University Press.

Davies, Christie. 2005. Jokes and groups. London: Institute for Cultural Research.

Hall, Edward T. 1978. Ukryty wymiar, trans. Teresa Hołówka. Warszawa: PIW.

Hall, Edward T. 1999. Taniec życia. Inny wymiar czasu, trans. Radosław Nowakowski. Warszawa: Muza.

Hofstede, Geert. 2000. Kultury i organizacje. Zaprogramowanie umystu, trans. Małgorzata Durska. Warszawa: PWE.

Piekot, Tomasz. 2012. Pictorial representation of idioms in Internet humour. In Laineste, Liisi \& Brzozowska, Dorota \& Chłopicki, Władysław (eds), Estonia and Poland. Creativity and tradition in cultural communication, 149-165. Tartu: ELM Scholarly Press.

Raskin, Victor. 1985. Semantic mechanisms of humor. Dordrecht: Reidel Publishing Company.

Skarga, Barbara. 1989. Granice historyczności. Warszawa: PIW.

Szopski, Marek. 2005. Komunikowanie międzykulturowe. Warszawa: WSiP.

Trompenaars, Alfons \& Hampden-Turner, Charles. 2002. Siedem wymiarów kultury. Znaczenie różnic kulturowych w działalności gospodarczej, trans. Bogumiła Nawrot. Kraków: Oficyna Ekonomiczna.

\section{Sources}

Badeni, Joachim \& Syrek, Judyta. 2010. Uwierzcie w koniec świata!: wspótczesne proroctwo o powtórnym przyjśsiu Chrystusa. Kraków: Znak.

Browne, Sylvia \& Harrison, Lindsay. 2011. 2012? Dni ostatnie wedtug proroków i wielkich religii świata, trans. Anna Wojtaszczykowa. Studio Emka.

Clifford, Paula. 1999. Krótka historia końca czasów, trans. Tadeusz Szafrański. Warszawa: PAX. 
Cuomo, Franco. 1999. Wielkie proroctwa: nowy klucz do odczytania najstynniejszych przepowiedni $w$ dziejach, od starożytnego Egiptu do Biblii, od Nostradamusa do Fatimy. Kraków: Universitas.

Gaspari, Antonio \& Cascioli, Riccardio. 2011. 2012: Katastrofizm i koniec czasów, trans. Marcin Masny. Wydawnictwo Św. Stanisława BM.

Gudzowski, Zdzisław. 2004. Proroctwa biblijne: Księga Daniela, Apokalipsa św. Jana: naukowo-historyczne studium o spetnionych i niespetnionych proroctwach biblijnych. Kraków: Impuls.

Hildegarda z Bingen. 2012. Antychryst $i$ koniec świata. Tyniec: Wydawnictwo Benedyktynów.

Kitrasiewicz, Piotr. 2010. Rok 2012: Apokalipsa nadchodzi? Warszawa: Jirafa Roja.

Kowalczyk, Dariusz \& Rowiński, Tomasz. 2012. Czy żyjemy w czasach Apokalipsy? Kraków: M.

Meszko, Tadeusz. 2009. 2012 Gniew Ojca. Dzieci Stońca. Stawiguda: Solaris.

Pastusiak, Longin. 1999. Czy nastapi koniec świata? Warszawa: Muza.

Paulus, Stefan. 1998. Nostradamus: kto przetrwa?, trans. Krzysztof Oparski. Wrocław: Astrum.

Thompson, Damian. 1999. Koniec czasu: wiara i lęk w cieniu millenium, trans. Bogumiła Nawrot. Warszawa: Prószynski i S-ka.

Tornielli, Andrea \& Gaeta, Saverio. 2012. A.D. 2012: czy nadchodzi koniec świata?, trans. Agata FerensKręciszewska. Kraków: Znak.

Zimmerling, Dieter. 2000. Od końca do końca: rzecz o radościach eschatologicznych, trans. Tadeusz Szafranski. Warszawa: PAX. 